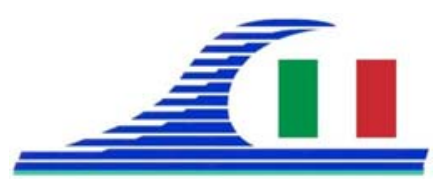

Conférence Méditerranéenne Côtière et Maritime EDITION 3, FERRARA, ITALIA (2015)

Coastal and Maritime Mediterranean Conference

Disponible en ligne - http://www.paralia.fr - Available online

\title{
The historical practice of disposal of dredged sediments in the Marano and Grado Lagoon: evaluation of geomorphological, evolutionary and functional perspective of the resulting artificial saltmarshes
}

\section{Annelore BEZZI ${ }^{1}$, Eleonora DRIUSSO ${ }^{1}$, Davide MARTINUCCI ${ }^{1}$, Giorgio FONTOLAN ${ }^{1}$}

\author{
1. Università degli Studi di Trieste Dipartimento di Matematica e Geoscienze, \\ via Weiss 1, 34128 Trieste, Italy. \\ bezzi@units.it
}

\begin{abstract}
:
An inventory was conducted of the present saltmarshes whose origin is due to the dredging and sediment disposal subsequent to an important waterway carried out in the early 1900 in the Marano and Grado Lagoon, a Special Area of Conservation (SAC) located in the northern Adriatic Sea. Morphology, evolution and habitat distribution were investigated by means of field surveys and topological analysis in GIS, using air photo for the period 1954-2011. Considering the overall maintenance of saltmarshes after 57 years since the sediment disposal, the frequent presence of near-natural morphologies and the subsequent development of Natura 2000 habitats, it is possible to state that building saltmarshes with dredged sediment has achieved good results during time. The historical practice of re-using dredged sediments for morphological and habitat restoration could be re-proposed as best practice for an effective conservation and management of the lagoon.
\end{abstract}

Keywords: Saltmarshes reconstruction, Natura 2000, GIS analysis.

\section{Introduction}

The Marano and Grado Lagoon is an extremely important wetland located in the northern part of the Adriatic Sea (Figure 1), a Special Area of Conservation (SAC IT3320037) according to Natura 2000 (Nature European Directives). It covers an area of $160 \mathrm{~km}^{2}$ and presents morphological signals typical of a sediment starved (deficit) lagoon as flattening and deepening of tidal flats, reduction of saltmarshes extent, channel silting up. It is also an interesting example of conflict due to the close interaction between natural and human forcing factors. Also, it has a pressing need for effective conservation and management, i.e. channel dredging has become a focus problem and there is a debate about the possibility to use or not the dredged sediment to restore salt marshes.

The conservation of saltmarshes originated after sediment disposal from dredging works for a lagoon waterway in the early 1900 (CUCCHINI, 1924) has been a good 
Côtes méditerranéennes menacées :

Risques et défis dans le contexte du changement climatique

opportunity to investigate the fate of the sediment which was historically dumped on the sides of the channels.

\section{Materials and methods}

It was achieved an inventory of the present saltmarshes resulting from dredging of waterways inside the lagoon, thanks to a previous map of GATTO and MAROCCO (1992), to geographical evidence and to historical records (CUCCHINI, 1924).

Evolution and morphological aspects of saltmarshes were topologically analyzed using GIS, starting from different sets of aerial photographs: 1954, 1990, 2004, 2008 and 2011. The presence and distribution of habitats were investigated through the analysis of the habitat map of POLDINI et al. (2006). Field surveys (consisting of topographic and recent sedimentary facies analysis) were carried out in 2012 in two sites.

\section{Results}

A total of 31 saltmarshes (24.3 ha) were identified as originated from past dredging works which involved the dumping of sediment on the channel side. Considering the whole time span investigated (1954-2011) a general increase of saltmarshes area is observed, amounting to 8.16 ha within 57 years (50.6\% of the original extent of 16.12 ha) (Figure 1). During 1954-1990 a significant increase in marsh extent with a total rate of $0.19 \mathrm{ha} / \mathrm{y}$ has to be related either to a natural development (+5.9 ha) either to the disposal of dredged sediment along a new channel, which created 1.15-ha-wide saltmarshes. The enlargement of the artificial saltmarshes continued to occur during 1990-2004 (+0.11 ha/y). A stabilization and slight decline of the morphologies were observed after 2004, with values of $-0.02 \mathrm{ha} / \mathrm{y}$ for the span 2004-2008 and $-0.07 \mathrm{ha} / \mathrm{y}$ for 2008-2011. The overall trend varies at local level, according to the hypothesis that local forcing factors, as sheltered or exposed settings, vessel traffic, wind exposure, presence of rock revetment, direct human actions and sediment characteristics, significantly constrain the evolution of artificial saltmarshes during time. Considering the percentage of gain/loss area during the 1954-2011 period for each individual saltmarsh, results indicate that 13 cases show a gain comprised between 10 and 643\%, 10 cases a loss lower than $50 \%$ and 8 greater.

Different morphological types have been recognized in the present landscape (Figure 2): alignment of primary pans associated with rapid increase of area (type A, 4 cases), complex pans with serpentine or irregular basins associated with drowning trend (type B, 18 cases), vegetation patches associated with recent colonization (type C, 5 cases), elevated banks remains of original dumping (type D, 5 cases).

It is worth noting that the type $\mathrm{D}$ marshes, featuring elevated banks due to the concentration of the most of the sediment dumped on the channel side, had promoted the sedimentation on nearby tidal flats, activating the development of a near-natural morphological gradient. 


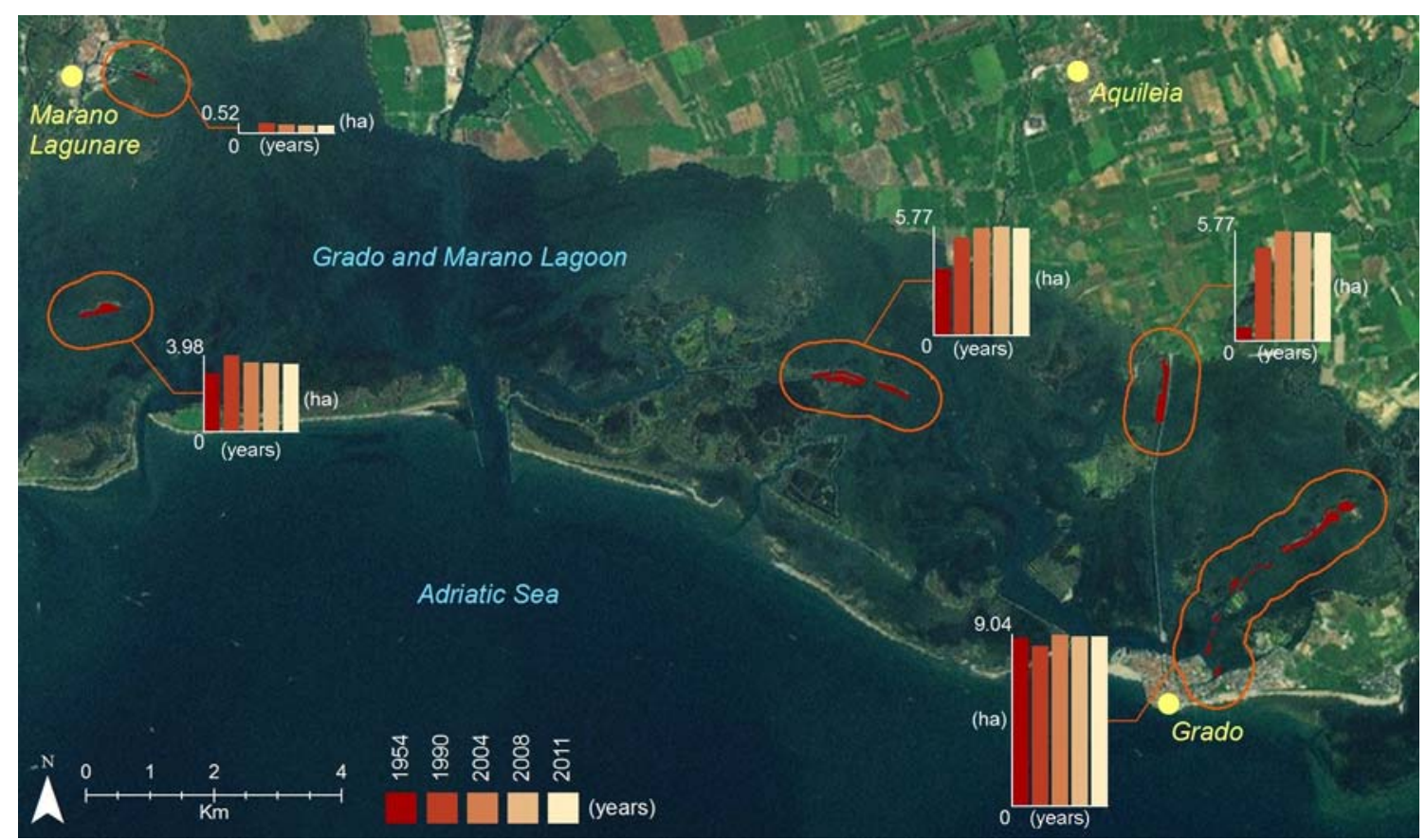

Figure 1. Distribution and changes in extent during time of saltmarshes originated from historical practice of disposal of dredged sediments in the Marano and Grado lagoon.

Recent stratigraphy confirms the anthropogenic origin of some of the investigated saltmarshes: bottom sediment (from 21 to $40 \mathrm{~cm}$ ) appears typical of disposal, and the top sequence shows saltmarsh facies consistent with those observed in the natural cases.

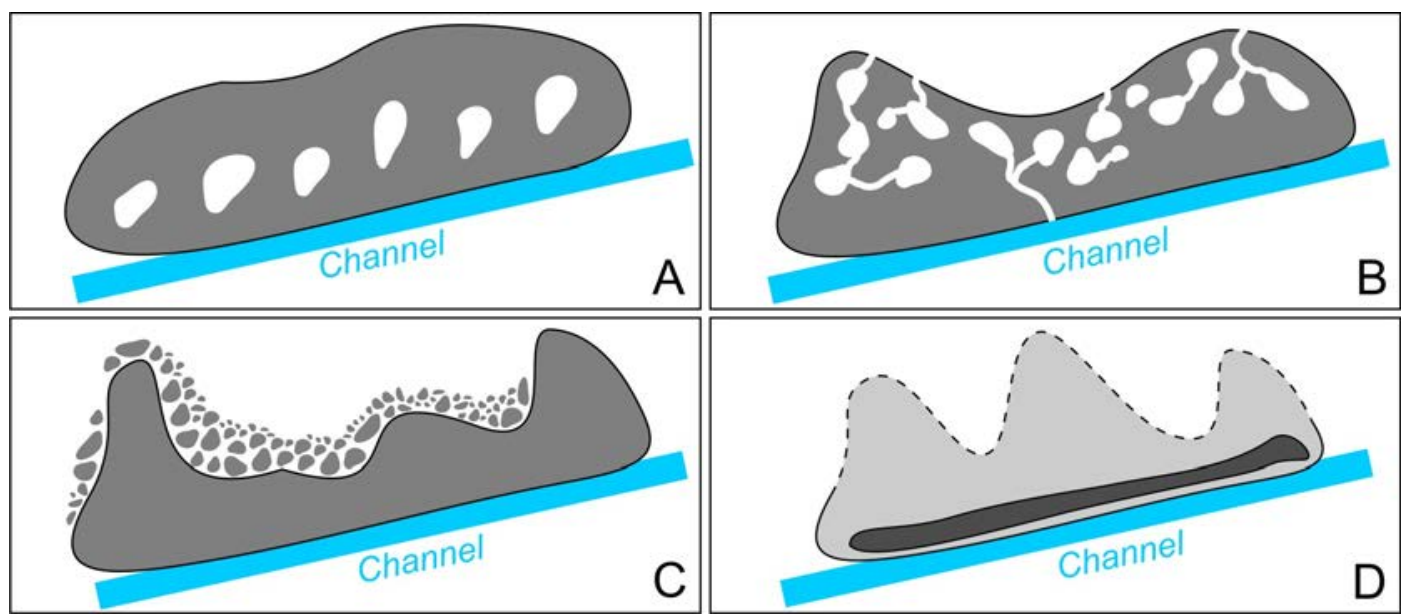

Figure 2. Simplified representation of morphological types identified in this study: A. alignment of primary pans, B. complex pans, C. vegetation patches, D. elevated banks.

The analysis of the habitat distribution shows that most of the habitats identified on the artificial saltmarshes are those typical of the natural ones, and recognized as Natura 2000 habitats (Figure 3A). Comparison with the extent of the same habitats on the 
Côtes méditerranéennes menacées :

Risques et défis dans le contexte du changement climatique

whole lagoon (Figure 3B) stresses the significance of studied saltmarshes in term of ecosystem conservation.

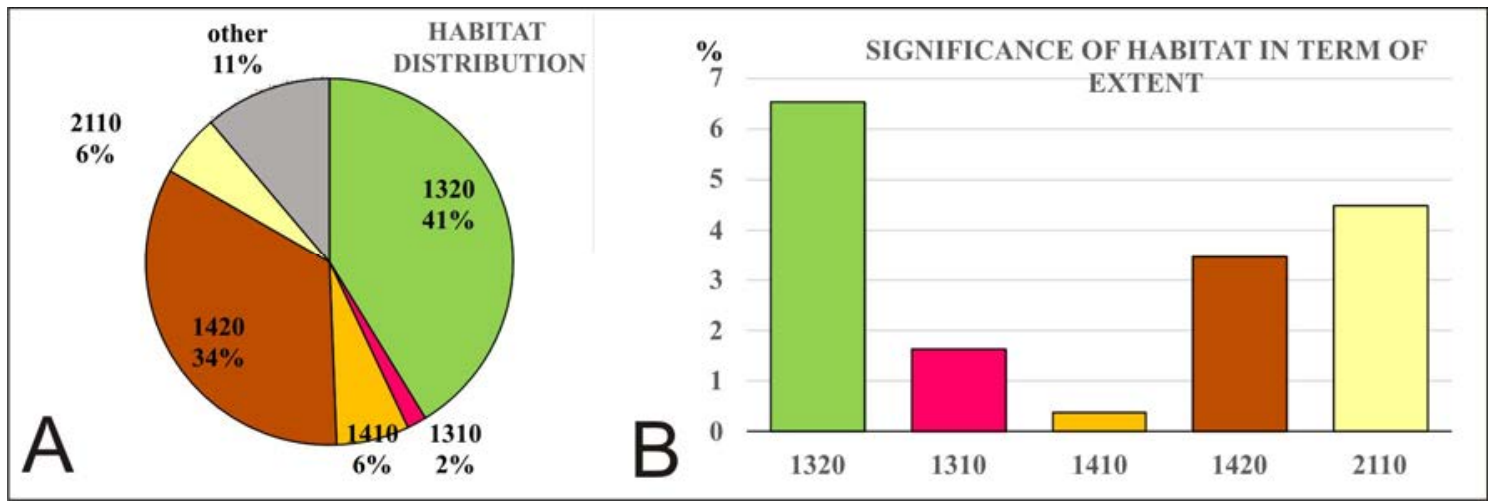

Figure 3. Distribution of habitat Natura 2000 on the artificial saltmarshes (A) and with respect to the extension on the whole lagoon (B). The numerical codes 1320, 1310, 1410, 1420, 2110 are those used by Natura 2000 (http://eunis.eea.europa.eu).

\section{Conclusions}

On the sedimentological, morphological and ecological point of views the studied sediment disposal has evolved in artificial saltmarshes that are very similar to the natural morphologies, therefore suitable for a functional restoration. Considering their favorable evolution it is possible to state that building saltmarshes with dredged sediment has achieved good results during time. Hence it is proposed to further the practice of re-using the dredged sediment in the Marano and Grado lagoon, where the building of new saltmarshes has not been undertaken yet.

\section{References}

CUCCHINI E. (1924). Cenni sui lavori di completamento della via d'acqua interna tra i fiumi Brenta ed Isonzo eseguiti durante la guerra (1915-1918). Estratto dagli Annali dei Lavori Pubblici, Vol. 11, pp 4-41.

GATTO F., MAROCCO R. (1992). Caratteri morfologici ed antropici della Laguna di Grado (Alto Adriatico). Gortania, Atti del Museo Friulano di Storia Naturale, Vol. 14, pp 19-42.

POLDINI L., ORIOLO G., VIDALI M., TOMASELLA M., STOCH F., OREL G., (2006). Manuale degli habitat del Friuli Venezia Giulia. Regione Autonoma Friuli Venezia Giulia 